\title{
OBITUARIES
}

\section{Sir John Parsons, C.B.E., F.R.S.}

John Herbert Parsons, who died on October 7, was born in 1868. He was educated at the University of Bristol, where he won many distinctions, and at University College, London. In 1890 he obtained the B.Sc. (Lond.) with honours in physiology. This subject remained his main interest, especially that part of it which concerned visual and cerebral function.

He qualified from St. Batholomew's Hospital in 1892 with the M.B. (Lond.). In 1900 he obtained the B.S. (Lond.) and the F.R.C.S. Eng. In 1901 he was granted a British Medical Association Scholarship and in 1904 obtained the D.Sc. (Lond.).

Parsons decided to become an ophthalmic surgeon, and his first appointment was as curator and librarian to the Royal London Ophthalmic (Moorfields Eye) Hospital. In this post he had control of the patho. logical laboratory and there laid the foundation and did the necessary research for his great work, "Pathology of the Eye", published during 1904-8. This became the standard work on this subject, and even to-day is a much-used work of reference.

In due course he became surgeon to the Moorfields Eye Hospital and ophthalmic surgeon to University Colloge Hospital and also for a while to the Hospital for Sick Children, Great Ormond Street, London.

Parsons's private practice was carried on at 54, Queon Anne Street, in the house previously occupied by his senior colleague, Mr. Marcus Gunn. The practice grew rapidly, but in spite of this and his ordinary work at the hospitals, he continued his laboratory and research work. In 1903 he was Arris and Gale lecturer at the Royal College of Surgeons. In 1904 he was awarded the Middlemore Prize in ophthalmology and in 1907 the Nettleship Gold Medal. In 1907 he published a small text-book, "Diseases of the Eye". This became very popular, and its tenth edition appeared in 1942.

In the last years of the First World War he was appointed consulting ophthalmic surgeon to the Army in the United Kingdom, and was given the rank of colonel A.M.S., with the task of co-ordinating and regulating the ophthalmic work of the Army. The result was as perfect an eye service as could be managed with the available resources.

All this special knowledge was of use to various ministries and institutions. In 1919 he served on the Advisory Committee of the Air Ministry and in 1922 at the Admiralty; at the Board of 'Trade on various subjects-...sight tests, factory lighting, prevention of blindness ; and on the Royal Society's Committee on Glass Workers Cataract. In 1928-32 ho was a member of the Medical Research Council. In 1919 he was appointed C.B.E., and in 1922 he was knighted.

In 1919 he was president of the Illuminating Engineering Society and many will remember his inaugural address on "Glare".

In 1917 the British Journal of Ophthalmology was founded by the amalgamation of several small publications, and Parsons became the chairman of the editorial board. He devoted much time to this, and it is due to him that this journal obtained and main. tained such a very high standard. He continued this work until his retirement from practice in 1939 .
In 1936 he was awarded the Howe Medal (United States), and this was a tribute to his international standing as a scientific ophthalmologist. It was during these years that many honours camo to him--Hon. LL.D. Edin., Hon. D.Sc. Bristol, Fellow of University College, London, Fellow and president of the Royal Society of Medicine, president of the Ophthalmological Society of the United Kingdom, honorary member of the American Medieal Association and of the Australian Ophthalmological Society. Then came the theoretical books, "Mind and the Nation" in 1918 and "Introduction to the Study of Colour Vision". These earned him election to the Royal Society in 1921 , and in that year came the "Introduction to the Theory of Perception", which set the seal on his ominence as a philosopher and seientist.

Parsons was a tall, thin man, very modest, rather shy, and he eschewod publicity. He appreciated economy in the use of words, and this sometimes made his published works difficult to follow. He was a shrewd judge of people, no respecter of persons and possessed a mordant wit. The outstanding feature of his character was his intellectual honesty: no hypocrisy, no humbug, no attempt at placating people, no dubious compromises and no pretence. Altogether a life devoted to science and to the welfare of humanity. A. Haroud Lery

\section{Dr. Kathleen M. Drew}

The death of Dr. Kathleen M. Drew (Mrs. Wright Baker) on September 14 has brought to a tragically early close a career of distinguished and devoted work in phycology in the very difficult field of the red algae. Most of this work was associated with the Department of Cryptogamic Botany in the University of Manchester, where she graduated in 1922, and later worked as a member of staff and as research fellow, first with Prof. W. H. Lang and later with Prof. C. W. Wardlaw; she received the degrec of D.Sc. of the University of Manchester in 1939. Dr. Drew was one of the earliest of the Commonwealth Research Fellows and spent two years in the United States, chiefly at the University of California, where some of her early systematic studies on the red algae culminated in the publication of her monograph, "A. Revision of the Genera Chantransia, Rhodochorten, and Acrochaetium" ; in later studies of this period of her work, for example, on Spermothamnion and Plumaria, she devoloped the cytological techniques which formed a basic part of her later work.

After hor marriage with Prof. H. Wright Baker, she maintained and developed her interests in the red algae with singular success alongside those of her very happy family life. With the publication in 1944 in Biological Reviews of her review on the nuclear and somatic phases in the Florideae, sho set the stage for the later developments in her work, where she made notable advances in linking morphological and cytological observations with cultural and physiological investigations into the life-histories and inter-relationships in the Rhodophyceae, that most varied and interesting group of algae. Perhaps one of the most striking results of this exporimental attack was the identification of Conchocelis rosea as 